UDC 94(477.83/.86)(092):378.4(477.83-25)

DOI: $10.24919 / 2519-058 x .17 .218185$

\title{
Wieslaw MACIERZYŃSKI
}

PhD hab. (History), Professor of Casimir Pulaski University of Technology and Humanities in Radom, 29 Malczewskiego Street, Radom, Poland, postal code 26-600 (cpi@uthrad.pl)

ORCID: 0000-0003-4466-977X

\section{Yuliya GLADO}

PhD (Law), Associate Professor of Ivan Franko National University of Lviv, 1 Universytetska Street, Lviv, Ukraine, postal code 79000 (yuliya.glado@gmail.com)

ORCID: 0000-0001-7606-8069

\section{Leonid TARASENKO}

PhD (Law), Associate Professor of Ivan Franko National University of Lviv, 1 Universytetska Street, Lviv, Ukraine, postal code 79000 (tarasenkoleo@gmail.com)

ORCID: 0000-0003-4359-8965.

\section{Веслав МАЦСЖИНСЬКИЙ}

доктор історичних наук, професор Університету Технологічно-гуманістичного імені Казимира Пуласького у Радомі, вул. Мальчевського, 29, м. Радом, Республіка Польща, індекс 26-600 (cpi@uthrad.pl)

\section{Юлія ГЛАДЬО}

кандидатка юридичних наук, дочентка Львівського начіонального університету імені Івана Франка, вул. Університетська, 1, м. Львів, Україна, індекс 79000 (yuliya.glado@gmail.com)

\section{Леонід ТАРАСЕНКО}

кандидат юридичних наук, доиент Львівського національного університету імені Івана Франка, вул. Університетська, 1, м. Львів, Украӥна, індекс 79000 (tarasenkoleo@gmail.com)

Bibliographic Description of the Article: Macierzyński, W., Glado, Yu. \& Tarasenko, L. (2020). Stanislav Dnistryanskyi and Lviv University: the prosopographic research. Skhidnoievropeiskyi Istorychnyi Visnyk [East European Historical Bulletin], 17, 79-89. doi: 10.24919/2519-058x.17.218185

\section{STANISLAV DNISTRYANSKYI AND LVIV UNIVERSITY: THE PROSOPOGRAPHIC RESEARCH}

Abstract. The purpose of the research is to depict Professor Stanislav Dnistryanskyi's scientific and public activity during his work at Lviv University and the Austrian Parliament, to determine the conceptual provisions substantiated by the scientist concerning the Ukrainian society's national state and historical legal perspectives. The methodology of the research is based on the general historical principles of systematization, scientific objectivity; the principles of historical and legal 
research and socio-historical methods (problem historical, historical systemic, problem chronological, historicaltypological, etc.) were introduced into the scientific circulation. The scientific novelty is that for the first time a systematic work was done and dedicated to S. Dnistryanskyi's activities at Lviv University on the background of the major social events in Galicia at the end of the XIXth - at the beginning of the XXth century. The Professor's participation in the Ukrainian struggle for the national university in Lviv is considered to be a separate scientific direction in the work. S. Dnistryanskyi's work has been presented in the State Council in Vienna in 1907 - 1918 and its relation to the main Galicia social problems of the studied time has been shown. The scientist's conceptual positions concerning the Ukrainian people's national policy and law, national self-determination, national-state prospects have been determined. The study expands the Ukrainian scientists' prosopography, whose careers have been connected with Lviv University. The Conclusions. S. Dnistryanskyi's activity was connected with Lviv University, where he was formed as a scientist and public figure, and the scientist's scientific work was implemented at the Department of Austrian Civil Law with the Ukrainian as the language of instruction, where he organized lectures and legal seminars on Civil and Constitutional law, expanded and created the Ukrainian legal terminology; defended the Ukrainian language rights in the educational process, based on the principles of the "Basic Austrian Law..."; together with M. Hrushevskyi, S. Rudnytskyi and the others joined the movement for a Ukrainian university in Lviv. Furthermore, S. Dnistryanskyi combined work at the department with work at the T. Schevchenko Scientific Society (SSS), publishing activities, the Ukrainian lawyers'structures creation. During 1907 - 1918 he was an Austrian Parliament member, without leaving the work at the department. In the State Council S. Dnistryanskyi defended not only the Ukrainian university opening issue but also the other Ukrainian society's nagging problems at that time: the preparation and the elections' holding to the Austrian Parliament and the Galician Sejm; the national issue; the census in Galicia; the land reform and forest lands economic problems. During this period, the scientist introduced into the scientific circulation the theoretical and methodological principles of statistical research; the historical and legal bases of the policy and the norms of law; the historical bases of the Ukrainian people's self-determination and its national state prospects. S. Dnistryansky's activity study expanded the Ukrainian scientific prosopography of Lviv at the end of the XIXth - at the beginning of the XXth century.

Key words: Stanislav Dnistryanskyi, Lviv University, Civil Law, SSSh, Ukrainian University.

\title{
СТАНІСЛАВ ДНІСТРЯНСЬКИЙ І ЛЬВІВСЬКИЙ УНІВЕРСИТЕТ: ПРОСОПОГРАФІЧНЕ ДОСЛІДЖЕННЯ
}

\begin{abstract}
Анотація. Мета дослідження - показати наукову та громадську діяльність професора Станіслава Дністрянського в період його працу у Львівському університеті та австрійському парламенті, визначити концептуальні положення, обтрунтовані вченим, щуодо національнодержавних та історико-правових перспектив украӥнської суспільності. Методологія дослідження базується на загальноісторичних принципах системності, науковоїоб 'єктивності; принципах історико-правових досліджень та соціально-історичні методи (проблемноісторичний, історико-системний, проблемно-хронологічний, історико-типологічний та ін). Наукова новизна дослідження полягає у тому, ш⿻ вперше створено системну роботу, присвячену діяльності С. Дністрянського у Львівському університеті на фоні головних суспільних подій у Галичині кіния XIX - початку XX cm. Як окремий науковий напрям у роботі розглядається участь професора у боротьбі україниів за національний університет у Львові. Представлено роботу С. Дністрянського у Державній Раді у Відні (1907-1918 рр.) і показано його ставлення до головних суспільних проблем Галичини досліджуваного часу. Визначено концептуальні положення вченого щчодо національної політики $і$ права, національного самовизначення, національно-державних перспектив українського народу. Виконане дослідження розширює просопографію украӥнських вчених, чия кар'єра була пов'язана із Львівським університетом. Висновки. Діяльність С. Дністрянського була пов'язана із Львівським університетом, де він сформувався як вчений $і$ громадський діяч, а наукова прачя вченого проходила на кафедрі австрійського ичивільного права з украӥнською мовою викладання, де він організував лекційний прочес $і$ правничі семінари з цивільного $і$ конституційного права, розцирив та створив украӥнську юридичну термінологію; відстоював права украӥнської мови у навчальному процесі,
\end{abstract}


виходячи із засад “Основного Австрійського Закону...”; разом з М. Грушевським, С. Рудницьким та ін. включився у рух за украӥнський університет у Львові. Працюю на кафедрі поєднував з роботою в НТШ, видавничою діяльністю, творенням структур українських правників. Протягом 1907 - 1918 рр. був депутатом австрійського парламенту, не залишаючи праці на кафедрі. У Державній Раді відстоював не лише питання відкриття украӥнського університету, а й інші актуальні проблеми украӥнської суспільності того часу: підготовка і проведення виборів до Австрійського парламенту і Галицького сейму; національне питання; перепис у Галичині; економічні проблеми земельної реформи і лісових угідь. У ией період вченим було введено до наукового обігу теоретико-методологічні засади статистичних досліджень; історико-правові основи політики і норм права; історичні підстави самовизначення українського народу та його національно-державних перспектив. Вивчення діяльності С. Дністрянського розширило украӥнську наукову просопографію Львова кіния XIX-початку XX cm.

Ключові слова: Станіслав Дністрянський, Львівський університет, иявільне право, НТШ, Украӥнський університет.

The Problem Statement. S. Dnistryanskyi's scientific and public activity is inextricably linked with Lviv University, where the scientist created his own school of the Civil Rights, advocated a separate Ukrainian university creation in Lviv. S. Dnistryanskyi took part in the National Movement, defending the Ukrainians' rights being in the role of a deputy in the State Council in Vienna.

The purpose of the research is to study S. Dnistryanskyi's scientific and public activities comprehensively, analyzeof his work at Lviv University, Schevchenko Scientific Society (SSS), the Ukrainian Lawyers Association creation, the parliamentary work.

The Analysis of Historiography and Source Base of the Research. The article analyzed S. Dnistryanskyi's unique publications, his speeches in the State Council in Vienna, the submitted appeals to the Senate of Lviv University, the Fund 26 materials (Lviv University) from the State Archives of Lviv region. In addition, the modern special editions analysis, devoted to S. Dnistryanskyi was carried out. Nowadays, the collective memory role in the Ukrainian historiography and the history of the national law is growing, which should reflect the university development science core stages, which belongs to Central and Eastern Europe intellectual area [Pomorskyi, 2020, p. 19; Kalakura, 2020, pp. 137-154]. However, Stanislav Dnistryanskyi's scientific and socio-political activity is presented in modern publications only in fragments. In particular, the work, written by P. Stetsiuk (Stetsiuk, 1999) highlights the scientist's activities as a constitutionalist; Polish researcher A. Redzik (Redzik, 2011, p. 448) submitted an encyclopedic article about S. Dnistryanskyi; Kyiv Publishing House published a bibliography of the scientist's works (Akademik Stanislav Dnistrianskyi, 1999); small syntheses in the legal encyclopedia (Usenko, Voznyi, 1999, pp. 213-220) and the Encyclopedia of the History of Ukraine (Isaievych, 2004, p. 445) were published about the scientist-lawyer. S. Dnistryanskyi's activity is sporadically presented in general works concerning the history and law of the last third of the XIXth - the first half of the XXth century.

The Statement of the Basic Material. S. Dnistryanskyi's activity is inextricably connected with Lviv University, where he evolved as a scientist and public figure. His work was aimed at the Austrian Civil Law Department organization and development at the University and a Ukrainian law school formation in Lviv. As a scholar, S. Dnistryanskyi belonged to the European legal tradition (graduated from the Law Faculty, the University of Vienna (1893); studied at the Universities of Leipzig and Berlin; Doctor of Law since 1894; habilitated doctor - Das Wesendes Werlieferungsvertages - since 1899). From 1898 until the Austria-Hungary collapse in 1918, S. Dnistryanskyi's scientific career was associated with the University of Lviv. 
Due to the radical changes in the Habsburg Empire, where in the 60-ies - 70-ies there were the decentralization reforms, which led to the formation in 1867 of Austria-Hungary as a new state structure, the socio political processes in Galicia in the last third of the XIXth century took place under the influence of the above-mentioned situation (Grzybowski, 1959).

Hence, Galicia, as a province, was given considerable administrative and political opportunities, and in addition to the institution of a governor, the Sejm, the participation of elected representatives in the Austrian parliament, it was represented in Vienna as the only administrative unit of AustriaHungary. The Polish political forces opportunities in the region, which were based on the traditional conservative principles and activities of the respective parties, increased, and the role of democratic structures and administration increased, regional and local, where mostly the Poles worked. The Polish political forces dominated Galicia clearly, creating "inconveniences" for the local Austrians, the Czechs, and the Jews, oppressing the Ruthenians (the Ukrainians) openly.

The Polish-Ukrainian confrontation was also expressed within the walls of Lviv University, whose administration Polonized the higher school. The Polonization process was especially active after 1869, when the Polish language received the official status in the region. At the same time, the Ukrainians sought to preserve and expand their rights in education. The students' participation in that process radicalized the Ukrainians demands, who felt discriminated against by the Polish leadership of the university. The national forces sought to increase the number of the Ukrainian departments (the department was considered "Ukrainian" when it was headed by a Ukrainian professor; the educational process was also conducted in Ukrainian) and to expand opportunities to teach in Ukrainian (Kachmar, 1999, p. 43)

On the $23^{\text {rd }}$ of October in 1869 , in connection with the decentralization reforms that "provided the Polish superiority", Yulian Lavrivskyi, then the Sejm Vice-Marshal, spoke about the Ukrainian demands. Yu. Lavrivskyi's program was based on the confirmation by the Galician Sejm of the "same interpretation" of the language issue and the introduction of the so-called "Government languages" - the Polish and the Russian (the Ukrainian). Accordingly, the "government languages" were to operate in the university, ensuring its "Utraquist" character. In fact, Yu. Lavrivskyi only started a discussion about the bilingual nature of the university, which gave grounds for the Sejm leaders to create a special language commission headed by Count Vladyslav Badeni. The administrative commission was formed on a parity basis: it included seven Polish representatives and seven Ukrainian ones. On the $4^{\text {th }}$ of July in 1871, Vienna presented an imperial decree on the "Utraquist" nature of the educational process at Lviv University. In particular, this document contained such phrases about the creation of a "free field for science" in Lviv Higher School and its development in "both regional languages" (Sukhyi, 2011, pp. 97-120; Sukhyi, 2013, p. 52).

The period of "obtaining docent" coincided with S. Dnistryanskyi at the time when in the mid-1890-ies even insignificant the Ukrainian national cultural movement achievements and the Ukrainians political demands strengthening were interpreted by the Poles as an encroachment on the "Polish Piedmont". The Polish-Ukrainian agreements, known as the "new era", also failed (Zashkilniak, 2013, p. 96; Chornovol, 2000)

At the same time, there was a clear structuring of the Ukrainian political environment the Russian-Ukrainian Radical Party, the Ukrainian National Democratic Party, the Ukrainian Social Democratic Party, which defined the national priorities and tasks. Including influenced the situation at the university.

Prior to the "New Era", four Ukrainian departments already functioned at Lviv University: two at the Law Faculty and two at the Philosophy Faculty (Philological Departments worked 
at the Philosophy Faculty). According to the Polish-Ukrainian agreements, supported by the Viennese government in 1894, a "Department of World History with a Special Review of the History of Eastern Europe" (Department of History of Ukraine) was opened, which was headed by Mykhailo Hrushevskyi (Pyrih, Telvak, 2017, pp. 100-102).

Social tensions that were characteristic of Galicia at the end of the XIXth century grew into a national conflict within the university between the Poles and the Ukrainians. The antagonism of relations between the Poles and the Ukrainians at the university was intensified also because the latter tried to give the Galician higher school an exclusively Polish character. The confrontation affected student circles and professors (Sukhyi, 2011, pp. 97-120; Mudryi, 2000, p. 176).

The general state of ethnic confrontation at the university was marked by another trend the democratization strengthening and the traditional Galician forces' positions weakening the aristocracy, the conservatives, the clergy and, at the same time, the entry into the political life of the lower classes - especially the peasantry. As a result, Lviv University students' social condition also changed. If during the previous time of the university, the Ukrainians were dominated by people from priestly families, small tenants of lordly estates, etc., then at the beginning of the XXth century representatives of peasant families, the bourgeoisie, and the intelligentsia clearly dominated. Some Ukrainians had experience of foreign earnings and invested their earnings in their studies. It was especially true among law students.

In 1898, S. Dnistryanskyi began his scientific career at the Austrian Civil Law Department with the Ukrainian language as the teaching language at Lviv University. S. Dnistryanskyi conducted lectures and legal seminars on Civil and Constitutional law, initiated the Ukrainian legal terminology creation and standardization, developed his own concept of state and law. Diverse scholar's scientific works appeared at the beginning of the XXth century, for example, the "Family Law" (1900), the "Austrian Law of Obligations" (1901 - 1903), "On the Reform of Private Law in Austria" (1912) (Burdin, Nor \& Boiko, 2016, p. 78)

While working at the department, S. Dnistrianskyi joined the discussion on the working language at Lviv University, defending the Ukrainians' right of their own language in higher education. He argued his position with the provisions of Art No. 19 on the "Basic Austrian Law..." and even devoted to the above-mentioned issue the scientific work "The Ruthenian Language Rights at Lviv University" (Dnistrianskyi, w.y.).

Work at the department was complicated by the general university situation. In particular, during 1898 - 1910, only two Ukrainian teachers obtained the highest legal teaching qualification - habilitation at the university. During the same period, habilitated professors from other universities came to the university and nine local Polish teachers were habilitated. Since 1870, the Ukrainian Dr. Ivan Dobryanskyi superseded the Polish lecturer, V. Srokovsky at the Criminal Law and Procedure Department, after whose death the Ukrainian Dr. Petro Stebelskyi became its professor. However, there were the teaching staff problems with the replacement at the second department: the Ukrainian language as the teaching language Department - the Austrian Civil Law Department: after Professor Omelyan Lopushanskyi's death in 1875, the department was left without a head. The university administration tried to present its candidacy and this provoked a negative reaction from the Ukrainians, hence, a long confrontation began between Lviv Ukrainian public and the University Senate. In 1882 1891 Professor Omelyan Ohonovskyi became a Professor of Civil Studies, but after his death, a conflict arose again. The Ukrainian public supported Mykhailo Zobkov, a Ukrainian lawyer from Bosnia, who presented his dissertation, but it was rejected by the University's Senate. Later on, M. Zobkov defended his dissertation at the University of Zagreb. Eventually, the 
University Senate decided to give Dr. Olexander Dolinsky, the Pole, a chance to take over, but the Ukrainian-Polish confrontation forced him to resign. Thus, for almost seven years the Civil Law Department management issue remained open (Kachmar, 2011, p. 9).

Finally, some changes occurred with S. Dnistyanskyi's appearance at the university. Owing to the administration, S. Dnistyanskyi became the habilitate doctor, which allowed him to become the first Associate Professor of the Austrian Civil Law, in 1901 - the Associate Professor, and in 1907 - ordinary Department's Professor. As a result, the Professor's status gave grounds to head the department.

Furthermore, S. Dnistryanskyi combined work at the department with the legal commission management work at the T. Schevchenko Scientific Society (SSS), the "Law Library" publication (1900 - 1909), was the "Legal and Economic Journal" editor-inchief $(1900$ - 1912). S. Dnistryanskyi initiated the the Ukrainian-Russian Lawyers Society establishment (Kachmar, 2011, pp. 9-11).

However, there were no cardinal changes at the Austrian Civil Law Department with the Ukrainian language as the language of teaching. Only in 1908, Dr. Volodymyr Verhanovskyi became an Associate Professor of the department. In general, in 1913 - 1914 the Law Faculty teaching staff consisted of 31 people, 9 of them were the Ukrainians.

In addition, S. Dnistryanskyi while working at Lviv University shared Mykhailo Hrushevskyi's views, defended the national paradigm clearly, which was associated with the Ukrainian movement for their own high school. The national position of citizenship was also supported by Ukrainian deputies in Lviv and Vienna. The Ukrainian higher education movement began in 1898, when a deputy from Galicia, Danylo Taniachkevych, addressed the State Council in Vienna. In his speech, he highlighted that the Ukrainian society seeks to establish its own national university, and the professional staff needed already formed at Ukrainian departments at Lviv University. The deputy, in particular, emphasized the university's tasks, which was supposed to carry out its high cultural mission, develop science and the human potential of science. D. Taniachkevych pointed to the civilizational role of the university in Lviv and throughout the country (Taniachkevych, 1898).

Oleksander Barvinskyi and Yulian Romanchuk demanded the Ukrainian university opening in Lviv on the $21^{\text {st }}$ of October in 1901 in the Austrian Parliament. They claimed that there were auspicious conditions in Lviv for the national university opening, but "There is not only the good will of the government on this issue, which meets only the needs of those peoples who have a large representation in the State Council” (Kachmar, 1999, p. 42).

The Ukrainian University Movement in Lviv was actualized by the national students. The students protests became the basis of the renowned secession, when students left Lviv University in whole groups and moved to other universities in Austria-Hungary - Vienna, Prague, Kosice, and the others. The movement gained mass character in December 1901 and ended in July 1902. Secession became an important stage in the struggle of national students for the Ukrainian higher education in Lviv and Galicia (Romaniuk, 1931, p. 134; Sukhyi, 2013, p. 67)

The Polish forces' attitude to the Ukrainian university opening issue in Lviv was not unambiguously defined. In particular, "Kurjer Lwowski" initially favored the Ukrainians, saying that the new Ruthenian university they planned to open in Lviv could not be a "threat to Polish culture" and that the presence of the two the Polish and the Ukrainian universities in Lviv would only promote the scientific competitiveness and science development ("Kurjer Lwowski”, 1901; Sukhyi, 2013, p. 67). 
As for the Polish university environment, Professor S. Stazhynskyi, who was also a member of the State Council in Vienna, argued that there was no formal reason to deny Ukrainians having their own university, arguing that they had the qualified staff. However, the Professor changed his position on this issue later (Kurliak, 1997, pp. 22-23).

The university problem was exacerbated by the political situation in Lviv. The Polish political structures in Lviv and Krakow, especially "vshekhpolyaky" (all the Poles), linked the university instability with the Ukrainian professors presence: S. Dnistryanskyi, Stepan Rudnytskyi (Shablii, 1999) and, especially, Mykhailo Hrushevskyi, who was treated as a "pro-Russian agitator".

In Galicia, the Polish Paramilitary structures were formed among the youth, for example, the "Stsheltsy", the "Sokols", and the others, who were involved in the university student environment and transferred street aggression to the walls of the university.

In May 1903, the Poles held a "National Congress of Polish Politicians" in Lviv in order to defend the "Polish state of affairs" in Galicia, which was attended by about 800 participants (Mykhalskyi, 2002, pp. 74-75).

Accordingly, Galicia and Bukovyna Ukrainians held a "secret meeting" in August 1903, where they rejected the possibility of any compromises with the Poles ( Zashkilniak, 2013, p. 97). As a result, the confrontation grew.

In 1907, Galicia held elections to the Austrian Parliament under a new election law. The Ukrainian university issue in Lviv was transferred to the higher Viennese offices. S. Dnistryanskyi became a member of Parliament and, accordingly, joined a new stage of the struggle for a Ukrainian university in Lviv.

On the $14^{\text {th }}$ of February in 1907, S. Dnistryanskyi, as a member of the deputy group, proposed a draft resolution recognizing the need for the government to establish a separate Ukrainian university. All national leaders joined the demand, and the document was signed by Yevhen Olesnytskyi and Metropolitan Andriy Sheptytskyi (Promova, 1907).

At the beginning of 1908, S. Dnistryanskyi, as a member of a group of the Ukrainian deputies, initiated the joint meetings in the Austrian Parliament with the Slovenes, the Croats, the Italians, and the Romanians in order to work out a joint resolution on the university question

The document called for the creation of an independent "Ruthenian university" to be established in five years. The beginning of this process was to be the allocation by the government at the beginning of the new school year of all Ukrainian departments in a "separate educational and scientific whole" (Redaktsiina stattia Dila, 1908; Sukhyi, 1913, p. 70). Contemporaries of events, the Ukrainian politicians from Kyiv V. Stepanovskyi and L. Yurkevych believed that the project was hindered by the event in Lviv, in particular, the murder of Galician governor Andrzej Potocki by a student, Myroslav Sichynskyi, and a significant advantage of the Polish and pro-Polish forces in the State Council (Stepanivskyi \& Yurkevych, 1908).

Another opportunity for S. Dnistryanskyi to exacerbate the Ukrainian university issue appeared in 1909, when the government's proposal to establish a Law Faculty in Vienna with the Italian language as the language of teaching was discussed. S. Dnistryanskyi together with O. Kolessa submitted a similar request to government agencies to establish a Ukrainian university in Lviv. However, on the $5^{\text {th }}$ of February in 1909 , the State Council session was closed, and the Ukrainian deputies request remained without consideration (Redaktsiina stattia "Ruslana", 1909).

Some S. Dnistryanskyi's and O. Kolessa's demands from the document were presented once again in 1910 when considering the university issue in the State Council: the Ukrainian 
deputies reminded of the drastic need to open a Ukrainian university constantly, while the Senate of Lviv University proposed to confirm by law "the Polish character of the university" (Sukhyi, 2013, p. 69). The position of the Ukrainians was the following: they agreed to a Polish university on the condition that a separate Ukrainian university be opened in Lviv.

S. Dnistryanskyi's work "in university affairs" was used in the debate during 1910-1913. The Ukrainian representatives demanded that the Ukrainian departments be separated into a separate autonomous university institution, which would enjoy the right to examinations and habilitation; later it was to be transformed into a Ukrainian university (Levytskyi, 1926). The Poles claimed that such a national university for the Ukrainians could be established in Stanislaviv, to which the Ukrainian side disagreed strongly.

During the pre-war period, the project of establishing a Ukrainian university in a five-year perspective remained effective, and till that time, the Ukrainians defended its "Utraquist" character (Redaktsiina stattia "Dila", 1912a).

The Polish position on the Ukrainian university was constantly changing and remained uncertain. In particular, during the pre-war period, they already stated that they would not help in the university establishment by training the Ukrainian personnel. The anti-Ukrainian position was shared by Lviv city authorities (Redaktsiina stattia "Dila", 1912b; SALR, f. 26, d. 13, c. 537, p. 3).

The main evidence of the confrontation aggravation at the university was that Adam Kots, the Ukrainian student, who studied law and was a youth activist, was murdered by the Polish militants in 1910. The clashes between the Polish and the Ukrainian youth within the walls of Lviv University carried on during the following years.

The Polish professors in Lviv also took an anti-Ukrainian position. In particular, they formed a special group from among themselves, which in 1909-1912 held secret meetings at Professor S. Stazhynskyi's apartment in order to prevent the "utraquisition" at Lviv University and "legislative support of its Polish character". As a result, the Ukrainian politicians formed the "Interparty Committee for the Affairs of the Ukrainian University" in May 1912, which was to support the Ukrainian university establishment in Lviv (Zashkilniak, 2013, p. 105).

However, the Ukrainian university opening issue in Lviv was not resolved. S. Dnistryanskyi's deputy activity during 1907 - 1918 concerned not only Lviv University issue, but also the issues concerning preparing and conducting elections to the State Council and the Galician Sejm, conducting censuses and detecting abuses during their implementation (Imprint, 1911), conducting land reforms, standardization of forest lands, etc.

A separate research area, which was suggested by S. Dnistryanskyi practice, was related to the national statistics, which he considered as a foundation for the socio-economic, legal and sociological research. The scientist identified the following statistics sections: the population statistics, the agricultural, the trade, the industrial, the labor, the school, the sanitary, the criminal and other types of statistics (Dnistryanskyi, b.r.).

Working in the State Council in Vienna, S. Dnistryanskyi did not leave the scientific work, in particular, during that period he defined the basic approaches to law and politics: he considered law as a norm of a public life, and considered politics a method that can guide this life. Hence, law and politics in his understanding were "inextricably connected", and changes in public life had to be associated with the norms to which it is subject. According to S. Dnistryanskyi, politics was possible only where there were legal norms and where there was a need to further develop it (Dnistrianskyi, 2019).

The Conclusions. S. Dnistryanskyi played an important role among the Ukrainian professors of Lviv University at the end of the XIXth - at the beginning of the XXth centuries, 
along with M. Hrushevskyi, S. Rudnytskyi and the others. Owing to S. Dnistryanskyi's scientific work, the Ukrainian School of Civil Rights was established, national associations of lawyers were formed, and the publication of special and periodical legal journals began. Furthermore, historical and legal research conducted by S. Dnistryanskyi at Lviv University allowed him to define the "Ukrainian statehood ideas", to substantiate the basis of selfdetermination as the Ukrainian people right, to reveal the content of historical, state and social synthesis in the social progress of the state and people.

S. Dnistryanskyi's public activity was aimed at the struggle for the Ukrainian university opening in Lviv; as a member of the State Council in Vienna, he influenced the solution of the national and social problems in Galicia.

The perspective for further research is to study S. Dnistryanskyi's scientific works on state and legal issues

Acknowledgments. We express sincere gratitude to all members of the editorial board for consultations provided during the preparation of the article for printing.

Funding. The authors received no financial support for the research and publication of this article.

\section{BIBLIOGRAPHY}

Akademik Stanislav Dnistrianskyi. (1992). Akademik Stanislav Dnistrianskyi. 1870 - 1935. Bibliohrafiia. [Academician Stanislav Dnistryansky. 1870 - 1935. Bibliography]. Kyiv: Vyd-vo NAN Ukrainy, 392 p. [in Ukrainian]

Burdin, V., Nor, V. \& Boiko, I. (2016). Yurydychnyi fakultet Lvivskoho natsionalnoho universytetu imeni Ivana Franka (1661 - 2016) [Faculty of Law, Ivan Franko National University of Lviv (1661 2016)]. Lviv: Vyd-vo Lviv. nats. un-t. im. I. Franka, 288 p. [in Ukrainian]

Chornovol, I. (2000). Polsko-ukrainska uhoda 1890 - 1894 rr. [Polish-Ukrainian Agreement 1890 - 1894]. Lviv: Lvivska akademiia mystetstv, 247 p. [in Ukrainian]

Derzhavnyi arkhiv Lvivskoi oblasti [State Archives of Lviv Region - SALR]

Dnistrianskyi, S. (2019). Zahalna nauka prava i polityky [General science of law and politics]. Lviv: Vydavnytstvo Ukrainskoho katolytskoho universytetu, 428 p. [in Ukrainian]

Dnistrianskyi, S. (b.r.). Natsionalna statystyka [National statistics]. Lviv: b.v. 48 p. [in Ukrainian]

Dnistrianskyi, S. (w.y.). Prava ruskoi movy u Lvivskim universyteti [The Rights of Ruska Language at Lviv University]. Lviv: b.v., 38 p. [in Ukrainian]

Grzybowski, K. (1959). Galicja. 1848 - 1914. Historia ustroju politycznego na tle historii ustroju Austrii [Galicia. 1848 - 1914. History of the political system against the background of the history of the Austrian system]. Kraków; Wrocław; Warszawa: Zakład Narodowy imenia Ossolińskich; Wydawnictwo Polskiej Akademii Nauk, 332 p. [in Polish]

Isaievych, Ya. (2004). Dnistrianskyi Stanislav Severynovych [Dnistrianskyi Stanislav Severynovych]. Entsyklopediia istorii Ukrainy (in 2 vol., Vol. 2, p. 688). Kyiv: Vyd-vo "Naukova dumka". [in Ukrainian]

Kachmar, V. (1999). Pytannia pro stvorennia ukrainskoho universytetu u Lvovi v avstriiskomu parlamenti na pochatku XX st. [The Issue of Ukrainian University Establishing in Lviv in the Austrian Parliament in the early twentieth century]. Lviv: misto - suspilstvo - kultura, 21-32. [in Ukrainian]

Kachmar, V. (1999). Za ukrainskyi universytet u Lvovi: Ideia natsionalnoi vyshchoi shkoly u suspilno-politychnomu zhytti halytskykh ukraintsiv (kinets XIX-pochatok XX st.) [For the Ukrainian University in Lviv: The Idea of a National Higher School in the Socio-Political Life of the Galician Ukrainians (late XIXth and early XXth centuries)]. Lviv: LNU imeni Ivana Franka, 169 p. [in Ukrainian]

Kachmar, V. (2011). Zmahannia ukraintsiv za natsionalni prava u Lvivskomu universyteti [Competitions of the Ukrainians for National Rights at Lviv University]. Kameniar, 1, 9. [in Ukrainian]

Kalakura, Ya. (2020). Zmina pokolin istorykiv yak metodolohichnyi ta svitohliadnyi dialoh v ukrainskii istoriohrafii (kinets XIX - pershe dvadtsiatyrichchia XXI st.) [Changing Generations of 
Historians as a Methodological and Ideological Dialogue in Ukrainian Historiography (the end of the XIXth - the first twentieth of the XXIst century).] Ukrainskyi istorychnyi zhurnal, 4, 137-154. doi: https:/doi.org/ [in Ukrainian]

"Kurjer Lwowski”. (1901). "Kurjer Lwowski”. 2 grudnia. [in Polish]

Kurliak, I. (1997). Ukrainska himnaziina osvita u Halychyni (1864 - 1918 rr.) [Ukrainian Gymnasium Education in Galicia (1864 - 1918).]. Lviv, 164 p. [in Ukrainian]

Levytskyi K. (1926). Istoriia politychnoi dumky halytskykh ukraintsiv. 1848 - 1914 [The history of political opinion of Galician Ukrainians. 1848 - 1914]. (in 2 vol.). Lviv, 536 p. [in Ukrainian]

Michalewska, K. (1984). Sprawa Uniwersytetu Ukraińskiego w latach 1848 - 1914 [The case of the Ukrainian University in 1848 - 1914]. Studia Historyczne, (1), 35-59. [in Polish]

Mudryi, M. (2000). Halytska avtonomiia v $70-80$-kh rr. XIX st.: ukrainske ta polske bachennia. [Galician Autonomy during the $70-80$-ies of the XIXth Century: Ukrainian and Polish Vision.] Ukraina: kulturna spadshchyna, natsionalna svidomist, derzhavnist, (7), 174-192. [in Ukrainian]

Mykhalskyi, Yu. (2002). Polski politychni partii ta ukrainske pytannia v Halychyni na pochatku XX stolittia (1902 - 1914) [Polish political parties and the Ukrainian question in Galicia in the early twentieth century (1902 - 1914)]. Lviv, 108 p. [in Ukrainian]

Pomorskyi, Ya. (2020). Velyka zmina: istoriia pered vyklykamy... Poslannia XX zahalnoho z'izdu polskykh istorykiv do istorykiv Tsentralno-Skhidnoi Yevropy [The Great Change: History Before Challenges... Message of the XXth General Congress of Polish Historians to Historians of Central and Eastern Europe]. Ukrainskyi istorychnyi zhurnal, 1, 19-30. doi: https:/doi.org/1015407/uhj2020.01.019 [in Ukrainian]

Promova. (1907). Promova posla d-ra Olesnytskoho v spravi Lvivskoho universytetu [Speech by Ambassador Dr. Olesnitsky on the case of Lviv University]. Ruslan, 30, 18 liutoho (3 bereznia). [in Ukrainian]

Pyrih, R. \& Telvak, V. (2017). Mykhailo Hrushevskyi. Biohrafichnyi narys. [Mykhailo Hrushevsky. Biographical Essay]. Kyiv: Lybid, 576 p. [in Ukrainian]

Redaktsiina stattia "Dila". (1908). O ruskyi universytet u Lvovi [About the Ruskyy University in Lviv]. Dilo, 64, 21 bereznia. [in Ukrainian]

Redaktsiina stattia "Dila". (1912a). Sprava ukrainskoho universytetu [The case of Lviv University]. Dilo, 95, 29 kvitnia. [in Ukrainian]

Redaktsiina stattia "Dila". (1912b). Sprava ukrainskoho universytetu [The case of Lviv University]. Dilo, 99, 4 travnia. [in Ukrainian]

Redaktsiina stattia "Ruslana". (1909). Zapytannia do ruskykh profesoriv universytetskykh i predstavnykiv ruskykh narodnykh tovarystv na z'izdi ukrainsko-ruskoi molodi [Questions to Ruskyy professors of universities and representatives of Ruskyy national associations at the Ruskyy youth meeting]. Ruslan, 148, 29 lypnia. [in Ukrainian]

Redzik, A. (2011). Dnistrianskyi Stanislav Severynovych [Dnistrianskyi Stanislav Severynovych]. Encyclopedia. Lvivskyi natsionalnyi universytet imeni Ivana Franka. (in 2 vol., Vol. 1, p. 448). Lviv: LNU imeni Ivana Franka. [in Ukrainian]

Romaniuk, A. (1931). Borotba za ukrainskyi khram nauky u Lvovi (1900 - 1914) [The Struggle for the Ukrainian Temple of Science in Lviv (1900 - 1914)]. Studentskyi shliakh, 7 - 8, 132-144. [in Ukrainian]

Shablii, O. (1993). Akademik Stepan Rudnytskyi - fundator ukrainskoi heohrafii [Academician Stepan Rudnytsky - the founder of Ukrainian geography]. Lviv; Miunkhen: vyd. viddil Lviv. un-tu, 392 p. [in Ukrainian]

Stepanivskyi, V. \& Yurkevych, L. (1908). Ves svit v ukrainskii spravi. Podiia 12 kvitnia 1908 roku [The whole world is in the Ukrainian cause. Event on April 12, 1908]. Kyiv, 36 p. [in Ukrainian]

Stetsiuk, P. (1999). Stanislav Dnistrianskyi yak konstytutsionalist [Stanislav Dnistryansky as a Constitutionalist]. Lviv: Lvivskyi derzhavnyi universytet im. Ivana Franka, 157 p. [in Ukrainian]

Sukhyi, O. (2011). Rozwój Lwowskiego ośrodka uniwersyteckiego na przełomie XIX $\mathrm{XX}$ w. Nauki prawne pomiędzy tradycją a wspótczesnością. Prace dedykowane Profesorowi Romanowi Longchamps de Berier w 70 rocznicę śmierci, 97-120. [in Polish] 
Sukhyi, O. (2013). Lvivskyi universytet na rubezhi XIX - XX st.: orhanizatsii, shkoly, hromadske zhyttia [Lviv University at the Turn of the XIXth - XXth Centuries: Organizations, Schools, Public Life.]. Visnyk Lvivskoho universytetu. Seriia istorychna. Yuvileine vydannia z nahody 350-richchia Lvivskoho universytetu, (49), 52-77. [in Ukrainian]

Taniachkevych, D. (1898). O ruskyi universytet u Lvovi [About the Ruskyy University in Lviv]. Dilo, (278-281), 1-3 hrudnia. [in Ukrainian]

Usenko, I. \& Voznyi, V. (1999). Dnistrianskyi Stanislav Severynovych [Dnistrianskyi Stanislav Severynovych]. Yurydychna entsyklopediia (in 6 vol., Vol. 2, pp. 219-220). Kyiv: Vydavnytstvo "Ukrainska entsyklopediia" im. M. P. Bazhana. [in Ukrainian]

Vidbytok. (1911). Interpeliatsiia posla Dra Dnistrianskoho i tovaryshiv do Ministra vnutrishnikh sprav shcho do spysovykh nad'uzhyt u skhidnii Halychyni [The interpellation of Ambassador Dra Dnistryansky and his comrades to the Minister of Internal Affairs regarding spears used in eastern Galicia], 11439-11447 p. [in Ukrainian]

Zashkilniak, L. (2013). Istorychna nauka v Halychyni na pochatku XX st. ta ukrainsko - polski vzaiemyny [Historical Science in Galicia at the beginning of the XXth Century and Ukrainian-Polish Relations]. Visnyk Lvivskoho universytetu. Seriia istorychna. Yuvileine vydannia z nahody 350-richchia Lvivskoho universytetu, (49), 93-113. [in Ukrainian]

The article was received on February 20, 2020. Article recommended for publishing 26/11/2020. 